\title{
Listeria monocytogenes IN MILK AND DAIRY PRODUCTS
}

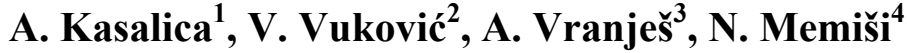 \\ ${ }^{1}$ JPS Dairy Institute, Auto put 3, 11070 Novi Beograd, Republic of Serbia \\ ${ }^{2}$ Scientific Veterinary Institute of Serbia, Auto put 3, 11070 Novi Beograd, Republic of Serbia \\ ${ }^{3}$ Faculty of Agriculture, Novi Sad, Square of Dositej Obradovića 8, 21000 Novi Sad, Republic of \\ Serbia \\ ${ }^{4} \mathrm{AD} »$ Mlekara«, Tolminska 10, 24000 Subotica, Serbia \\ Corresponding author: anka.kasalica@gmail.com \\ Review paper
}

Abstract: Listeria monocytogenes is ubiquitous bacteria. It causes listeriosis, a serious infectious disease which occurs as consequence of consumption of food contaminated with this pathogen bacterium. The frequency of incidence of listeriosis is low (1\%), but with high mortality rate $(30 \%)$. In certain countries (USA and Switzerland) large outbreaks of listeriosis were associated with consumption of fresh cheeses and milk. Studies on presence of L.monocytogenes in raw milk, carried out in Europe, have shown that 2,5-6\% of samples can be contaminated with L.monocytogenes. In the process of production of milk and dairy products, it most commonly occurs as consequence of post-pasteurization contamination. L.monocytogenes has the ability to multiply and grow at low temperatures $\left(4^{0} \mathrm{C}\right)$ and to survive even on freezing temperatures, and as such poses risk for health of consumers, if found in milk, cheese, ice-cream and other dairy products. In order to prevent the contamination of product with this bacterium, producers much implement prevention measures, and special attention must be focused on critical points in the production process and adequate sanitation. The general characteristics of L.monocytogenes, are presented in the study, also its resistance to environment, some listeriosis outbreaks, its presence in milk and dairy products and major hygiene measures.

Key words: Listeria monocytogenes, milk, dairy products.

\section{Introduction}

Milk and dairy products, because of their high nutritional value, are very suitable for development of microorganisms, including pathogenic bacteria (Farber and Peterkin, 1991; Kasalica, 2000). To which extent it will develop depends primarily on the type of product, chemical composition, manufacturing, storing, etc. 
Recently, special attention in the food industry has been directed to pathogenic bacteria Listeria monocytogenes. Nevertheless, until the sixties of the last century, L. monocytogenes was considered only to be cause of diseases in animals. Only after the discovery that L.monocytogenes can also cause many diseases in humans, the intensive study world wide of this bacterium started. Listeriosis is serious disease of humans, occurring sporadically or in the form of epidemic, with mortality rate of over 25\% (USDA, 1999).

The first communications/reports of the presence of Listeria in food are associated with dairy products, where cow milk is mentioned as carrier of the fatal listeriosis (Farber and Peterkin, 1991). According to many communications, consumption of milk and dairy products contaminated with L.monocytogenes can lead to individual cases of listeriosis or true outbreak of this disease. Of all dairy products, soft cheeses and non-pasteurized milk are most common causers of listeriosis. Two large outbreaks in human population were associated with consumption of soft cheeses. In California, from June to August 1985, 142 persons became ill, of whom 48 died (Linnan et al.,1988), and in Switzerland, in the period from 1983 to 1987, 122 cases were recorded, of which 34 died (Bille, 1990). Also, during 2005 in Switzerland, 10 cases were recorded with 3 death outcomes, where source of infection was soft cheese manufactured by local producer (Bille et al., 2006). In Massachusetts, the listeriosis outbreak in 1983 was associated with consumption of pasteurized milk (Fleming et al., 1985) which originated from a dairy farm where cattle were suffering from listeriosis. For long time it was considered that butter does not represent good environment for growth of L.monocytogenes, however, two outbreaks of listeriosis in Finland, in 1998 and 1999 were caused by butter (Lyytiksinen et al., 2000; Maijala et al. ,2001).

Mainly the reports obtained in developed countries speak of the presence of L.monocytogenes in food (Maijala et al., 2001; Melanie and Siegfried, 2001; Karakolev, 2009). Microbiological studies of the presence of L.monoytogenes in Europe have shown that 2,5- $6 \%$ of samples of raw milk can be contaminated with L.monoyitogenes, indicating potential risk for human population from dairy products manufactured from raw milk (Kozak et al., 1996; Donnelly, 2004). Rudolf and Siegfried (2001) studied the frequency of incidence of Listeria and L.monocytogenes in red smear cheese, in Europe. Various types of red smear cheeses were investigated/tested, and it was established that $15,6 \%$ of samples were contaminated with bacteria of Listeria genus, of which $6,4 \%$ were L.monocytogenes.

In dairy industry, many problems associated with L.monocytogenes contamination are related to post-pasteurization contamination. L.monocytogenes can survive for longer period at low temperatures and on process equipment, and the ability of bacteria to survive on the equipment used in production is often cause of the outbreaks described in the literature (Conly and Johnston, 2008). In studies by Pan et al. (2006) it is stated that strains of L.monocytogenes were isolated from equipment used in food industry which survived on the equipment and showed 
high resistance to sanitation measures, with ability to act as constant source of contamination.

In Serbia, the incidence of $L$. monocytogenes in milk and dairy products has not been sufficiently studied and therefore there is no objective picture of the situation and presence of this bacterium in domestic products. »Rulebook on general and specific food hygiene conditions in any stage of production, processing and trade " (Official Journal of RS, 72/10), the mandatory control/testing of food on presence of L.monocytogene is introduced, which will in future period result in realistic, objective picture of presence of this bacteria in milk and dairy products.

Taking into consideration that this is pathogen bacteria included for the first time in the Rulebook, and that Serbian expert public does not have enough experience with this issue, objective of our study was to present some general characteristics of L.monocytogenes, its pathogenicity, frequency of incidence in milk and dairy products and prevention measures.

\section{General characteristics of $L$. monocytogenes}

According to Bergey's Manual of Systematic Bacteriology (1994) Listeria genus includes: L. monocytogenes, $L$.ivanovii, $L$. innocua, $L$. seeligeri $L$. welshimeri and L. gray. L. monocytogenes is pathogenic for humans and animals, and L.ivanovii is mainly pathogenic for animals, primarily sheep. Other species are considered to be non-pathogenic. $L$.monocytogenes has thirteen serotypes, but the most common causes of disease are $1 / 2 \mathrm{a}, 1 / 2 \mathrm{~b}$, and $4 \mathrm{~b}$.

Members of the Listeria genus are short rods, facultative anaerobic, Gram positive, not forming spores and capsules, distributed individually and in form of short chains, sometimes in form of the letters V and Y. In direct smear they can be coccoid, and therefore mistaken with streptococci (Todar, 2009). In old cultures they form longer rods, with long filaments, and also Gram-negative units can occur. Listeria is mobile at the temperature of $20-25^{\circ} \mathrm{C}$ (they create peritrichous flagella) and immobile at $37^{\circ} \mathrm{C}$. They are catalase positive, oxidase negative, esculin hydrolysis positive. L. monocytogenes creates during exponential phase a toxin called listeriolysin $\mathrm{O}$ (hemolysin), which leads to in- vitro hemolysis on blood agar.

L. monocytogenes is widely spread in nature and has high resistance to external environment.

The effect of temperature. It is psychotroph with resistance to high temperatures. It has wide temperature range for growth. It multiplies at temperatures ranging from $-1,5^{\circ} \mathrm{C}$ to $45^{\circ} \mathrm{C}$. Optimal temperature for bacteria growth is $30-37{ }^{\circ} \mathrm{C}$.

The effect of $\mathbf{p H}$. L. monocytogenes reproduces/multiplies best at $\mathrm{pH}$ 7. It is resistant to acid $(\mathrm{pH}<5)$ and alkali $(\mathrm{pH} 9,6)$ environment.

Water activity $\left(\mathbf{a}_{\mathbf{w}}\right)$. It multiplies at $\mathrm{a}_{\mathrm{w}} 0,90-0,97$ and survives relatively low $\mathrm{a}_{\mathrm{w}}<0,90$. 
Halotolerant. L.monocytogenes grows at the $\mathrm{NaCl}$ concentration of more than $10 \%$. During one year period it survived in concentration of $16 \% \mathrm{NaCl}$, at $\mathrm{pH} 6,0$ (Seeliger and Jones, 1984). Conner et al. (1986) state that the resistance of $L$. monocytogenes to $\mathrm{NaCl}$ intensifies at lower temperatures. It can survive 100 days in concentration of $10,5-30 \% \mathrm{NaCl}$, at $4^{0} \mathrm{C}$.

Resistance to UV radiation. It is resistant to UV radiation which greatly contributes to wide spreading of this bacterium. Researches carried out by Bougle and Stahl (1994) confirm its resistance to gamma and X radiation. Doses of 2,6 $\mathrm{kGy}$ completely destroys $L$. monocytogenes $\left(10^{4} / \mathrm{ml}\right)$ in milk, but at concentration of $105 / \mathrm{ml}$ certain number of pathogens will survive for 45 days, however bacteria have lost the ability to reproduce.

Resistance to sanitation preparations/chemicals. L. monocytogenes is resistant to most of sanitation preparations/chemicals. Preparations that have proven to be the best in destruction of L.monocytogens are following: preparations on the basis of iodoform peracetic and peroctanoic acid, quarternary ammonium compounds and chlorine solutions (Tompkin et al., 1999; Schafer et al., 2000; Eifert et al., 2002).

\section{Listeriosis}

Listeriosis is infectious disease of humans and animals, caused in $99 \%$ of cases by consumption of food contaminated by L. monocytogenes, and rarely from the environment (Farber and Petrekin, 1991; Todar, 2009). Some cases of listeriosis in humans caused by eating dairy product are presented in Table 1.

The clinical picture in diseased humans and animals is manifested in similar way. In humans it can lead to following diseases: meningitis, encephalitis, septicemia, diarrhea, skin infections, etc. Particularly vulnerable groups are: pregnant women (miscarriages or stillborn children), infants, older persons and persons with weakened immune system (Todar, 2009). The presence of listeriosis in humans is low in the percentages $(1 \%)$, but with high percentage of fatal outcome (30\%) (Salamina, 1996; Vazquez- Boland et al., 2001). It is estimated that listeriosis annually causes 2500 of serious cases of illness with approx. 500 deaths (Marriott and Gravani, 2006). Also, the presence of this bacterium in intestinal tract of 5 to $10 \%$ of healthy humans without any obvious symptoms of the disease, was established (Todar, 2009).However, in healthy adult individuals it can be totally unnoticed or be illness like the flue. Sensitivity of humans towards L.monocytogenes is different and it depends on genetic predisposition (Shelef, 1989).

Infective dose for this bacterium is not precisely determined. Most of researchers consider the amount of 100-1000 L. mon./g of foodstuff to be enough to cause listeriosis in humans (Ooi and Lorber, 2005), and data on epidemic cases show values in range from $10^{7}-10^{11} \mathrm{cfu} / \mathrm{g}$ of foodstuffs (Dalton et al., 1997). 
Table 1. Listeriosis in humans caused by consumption of dairy products (McLauchlin et al., 2004)

\begin{tabular}{|c|c|c|c|c|}
\hline Country & Year & Foodstuffs & Total infected & Died \\
\hline USA & 1994 & Past. Chocolate milk & 45 & 0 \\
\hline France & 1995 & Fresh cheese & 17 & 4 \\
\hline Finland & $1998-1999$ & Butter & 25 & 6 \\
\hline USA & $2000-2001$ & $\begin{array}{c}\text { Mexican type of soft } \\
\text { cheese }\end{array}$ & 12 & 5 \\
\hline
\end{tabular}

Symptoms of infection with this bacterium can occur after incubation period in form of gastro-intestinal problems, muscle pains and high temperature. Listeria introduced into organism through food can enter through intestine wall, and from there in the blood stream, and through blood stream it reaches the central nervous system (brain and spinal cord). In pregnant women, it can be passed through placenta on to the foetus, and cause miscarriage, still birth or serious diseases in new born babies. Pathogenesis of this bacterium is based on its ability to survive and to multiply in phagocytes of the host (Mačvanin, 2004).

Listeriosis affects domestic and wild animals, most often sheep and cattle, rarely goats, horses and poultry. Cows can excrete listeria after miscarriage or during udder infections followed by mastitis, through milk. This can be manifested in some cases for several years. Contamination of milk by these bacteria can also be of faecal origin. In sheep affected by listeriosis in late stage of the disease paralysis and circle movement of the animal occur.

\section{Sources of contamination by $L$. monocytogenes}

It is widely spread in nature, easily enters the food and as such can lead to contamination of the food. The bacteria was isolated in the soil; vegetation; water (sweet, salty and sewerage); raw and processed food (milk and dairy products); production facilities (ranges, floors, forklifts, washing tubs, working tables, knives, cutting equipment and machines, aprons, ripening premises, cold stores, open space, etc.); secretions of sick individuals (McLauchlin et. al., 2004; Todda and Notrmansb, 2010).

Raw milk is one of the most common paths for transmission of L.monocytogenes, mainly due to sick animals on the farm. It is important to point out that healthy animals are often carriers of L.monocytogenes and as such can be source of contamination of the environment, or milk. There is the opinion that main source of contamination of animals by L. monocytogenes is poor quality of prepared silage (Fenlon, 1986). According to some literature data, listeria was isolated in 1,2-60\% samples as consequence of poor quality of prepared silage $(\mathrm{pH}$ > 5-5,6) (Fenlon, 1986; Vilar et al., 2007). Listeria spp. was isolated in 2-6,1\% samples of milk collected from cows fed silage (Vilar et al., 2007). Tasci et al. (2010) isolated L. monocytogenes in $6,66 \%$ silage samples, in $1,17 \%$. Of milk 
samples obtained from cows fed this silage, whereas the samples of milk from cows which were not fed the same silage were free of L. monocytogenes.

As already stated, facilities of dairy plants are excellent environment for development and growth of L.monocytogenes considering high moisture and milk and dairy product remains on equipment used in production. L.monocytogenes has the ability to form phybrils through which it attaches/adheres to solid surfaces, creating biofilm, which is reason why it is very difficult to remove it from the equipment and production facilities, where it multiplies on the equipment surface resulting in re-contamination of dairy products.

\section{Presence of $L$. monocytogenes in milk and dairy products}

In dairy industry, occasional presence of bacteria L. monocytogenes in milk, dairy products and dairy facilities/plant, is major problem.

Pasteurization of milk destroys L. monocytogenes. However, to which extent the L. monocytogenes is destroyed in milk during the process of pasteurization depends on the resistance of individual strains within the same species. Pasteurization of milk which occurs at the temperature of $62,8^{\circ} \mathrm{C}$ for 30 minutes and $71,7^{\circ} \mathrm{C}$ for 15 seconds is enough to destroy listeria present in the population of $10^{2} \mathrm{cfu} / \mathrm{ml}$, but not in the population of $10^{7} \mathrm{cfu} / \mathrm{ml}$ (Jayamanne and Samarajeewa, 2010). According to research by Pearson and Marth (1990), high pasteurization inactivates L. monocytogenes, but the minimum survival of the bacteria is still possible.

L. monocytogenes has the ability to reproduce at very low storage temperatures $\left(4^{0} \mathrm{C}\right)$, and some other pathogenic bacteria. This is major property of stated bacteria which can often be isolated at milk collection sites and in dairy facilities, which means that they can reach final dairy products (Wilkins et al., 1972; Kasalica and Otenhajmer, 1995a,b,c, 1996).

L. monocytogenes is resistant to freezing temperature during longer period of time. In sheep milk, frozen at $-38^{\circ} \mathrm{C}$, and subsequently stored at $-18^{\circ} \mathrm{C}$ and $-38^{0} \mathrm{C}$ during the period of 7,5 months, one strain of L.monocytogenes survived to great extent ( $95 \%)$, whereas the other strain, under same conditions, survived in a lesser degree (40-50\%). Destroying of L. monocytogenes in curdle of feta cheese obtained from said sheep milk stored under same conditions, was greater than in sheep milk (Papageorgiou et al., 1997). To which extent the L. monocytogenes develops or survives in milk and dairy products, stored at storage temperature or frozen, depends on the type of dairy product and strain of L. monocytogenes (El-Gazar et al., 1992; Theodoridis et al., 2006).

L. monocytogenes was isolated from raw milk, cheeses, dairy products and dairy plants. According to many authors, L. monocytogenes is most commonly isolated from raw milk sampled from collection tanks on farms or in dairy plants, and various contamination degrees have been recorded. In some countries the percentage of contaminated samples was relatively high, which speaks of potential 
danger from listeriosis if such milk is consumed without prior heat treatment (Table 2).

Table 2. Presence of Listeria monocytogenes in raw milk

\begin{tabular}{|c|c|c|c|}
\hline Country & Sampling location & $\begin{array}{c}\text { Presence of } \\
\text { L. } \text { monocytogenes\% }\end{array}$ & Reference \\
\hline Estonia & $\begin{array}{l}\text { Collection tank of the } \\
\text { farm and dairy plant }\end{array}$ & 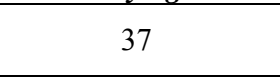 & Haekkinen et al., 2001 \\
\hline Scotland & $\begin{array}{l}\text { Collection tank of the } \\
\text { farm }\end{array}$ & 15,6 & Jay et al., 2005 \\
\hline Uganda & $\begin{array}{l}\text { Collection tank of the } \\
\text { dairy plant }\end{array}$ & 13 & Mugampoza et al.,2011 \\
\hline $\begin{array}{c}\text { The } \\
\text { Netherlands }\end{array}$ & Raw milk & 4,38 & Beckers et al., 1987 \\
\hline Sweden & $\begin{array}{l}\text { Silo tank of the dairy } \\
\text { plant } \\
\text { Collection tank of the } \\
\text { farm }\end{array}$ & $\begin{array}{c}19,6 \\
1\end{array}$ & Waak et al., 2002 \\
\hline USA & Raw milk & 4 & Pearson \& Mart, 1990 \\
\hline Iran & Raw milk in dairy plant & $1,7-3,3$ & Mahmoodi, 2010 \\
\hline Turkey & Raw milk & 1,17 & Tasci et al., 2010 \\
\hline
\end{tabular}

Research Kasalica and Oljačić (2007) showed that in 30 samples of raw milk (sheep, goat and cow milk) the presence of L.monocytogenes was not established). Also, during 2009, in samples of collective raw milk, sampled from three individual agricultural producers - holdings (33 samples) and from one dairy farm (11 samples) the presence of L.monocytogenes was not established (Kasalica and Popović-Vranješ, no published research).

Presence of L. monocytogenes in cheese can be associated with type of cheese, the manufacturing, inadequate pasteurization, post-pasteurization contamination, inadequate production, ability to multiply during storage at low temperatures and resistance to sanitation preparations (Bottarelli et al., 1999).

The composition of cheese, $\mathrm{pH}, \%$ of moisture, $\%$ of salt, ripeness of cheese, storing conditions, starter cultures and virulence of pathogens influence the reproduction of L. monocytogenes in cheese (Kovinčić et al., 1991). According to research conducted by many authors, cheeses produced from raw milk are more often contaminated with L. monocytogenes, compared to cheeses obtained from pasteurized milk. In Sweden, in samples (333) of soft and semi-soft cheeses collected from retail stores, L.monocytogenes was isolated in $6 \%$ of samples, of which $42 \%$ were produced from raw milk, and $2 \%$ from heat treated milk (Lončarević et al., 1995). Rudolf and Scherer (2001), as the result of repeated contamination of milk with L.monocytogenes, in $8,0 \%$ of cheeses produced from pasteurized milk, concluded the presence of L.monocytogenes. Jacqueta et al. (1990), in the period 1988-1990, analyzed 340 samples collected in a dairy plant from equipment, dairy production facilities and different types of cheeses, on 
presence of Listeria. L.monocytogenes was isolated in 44 tested samples of cheese, also from equipment and dairy production facilities; cheese was contaminated during the ripening process.

Soft cheeses and cheeses with mould represent excellent environment for reproduction/multiplying of $L$. monocytogenes (high \% of moisture and $\mathrm{pH}>4,2$ and 5,6). In researches carried out by Mc Lauchlin et al. (1990), soft cheeses, immediately after production, had low presence of $L$. monocytogenes $(<10 / \mathrm{g})$. However, after expiration date, their presence was significantly greater $\left(10^{5}\right.$ $10^{7} \mathrm{cfu} / \mathrm{g}$ ), indicating how these cheeses are suitable for development and growth of L. monocytogenes (Table 3).

In semi-hard cheeses, in later stages of ripening, the $\mathrm{pH}$ value increases which is also suitable for growth of L. monocytogenes.

Hard cheeses, because of low water content, are not the best environment for growth of this bacterium.

Table 3. Contamination of soft and semi-hard cheeses with Listeria monocytogenes

\begin{tabular}{|c|c|c|c|}
\hline Country & Cheese type & $\begin{array}{c}\text { Presence } \\
\text { L. monocytogenes } \%\end{array}$ & Reference \\
\hline Italy & \multirow{4}{*}{$\begin{array}{c}\text { Soft and semi-hard } \\
\text { cheeses (red smear } \\
\text { cheese) }\end{array}$} & 17,4 & \multirow{4}{*}{$\begin{array}{l}\text { Rudolf and Scherer } \\
\text { (2001) }\end{array}$} \\
\hline Germany & & 9,2 & \\
\hline Austria & & 10,0 & \\
\hline France & & 3,3 & \\
\hline England & $\begin{array}{l}\text { Soft and ripe cow } \\
\text { cheese }\end{array}$ & 8,2 & Greenwood et al. (1991) \\
\hline The Netherlands & $\begin{array}{l}\text { Imported soft cheeses } \\
\text { made of raw milk }\end{array}$ & 10,14 & Beckers et al. (1987) \\
\hline England & \multirow{2}{*}{$\begin{array}{c}\text { Retail cheese } \\
\text { Cheese in the dairy } \\
\text { plant (soft cheese) } \\
\text { Soft cheese }\end{array}$} & $\begin{array}{l}64,0 \\
50,0\end{array}$ & McLauchlin et al. (1990) \\
\hline Great Britain & & 10,0 & Pini and Gilbert (1988) \\
\hline Spain & Soft cheese & 8,1 & Vitas et al. (2004) \\
\hline
\end{tabular}

Lactic acid bacteria (LAB) slow down or stop the growth of pathogens in fermented products (Schaack and Marth, 1988; Haris et al.,1989; Kasalica, 1992; Kasalica,1997). Bacteria L. monocytogenes is characterized by different level of sensitivity to LAB.

In fermented products, L. monocytogenes has the ability to survive during production process and storing. It survives in yoghurt for several weeks depending on the degree of contamination by this bacterium (Zuniga-Estrada et al., 1995). In dairy products fermented by using different LAB strains fermentation of milk (L.bulgaricus,S.thermophilus and yoghurt), the survival of L. monocytogenes depended on the used strain of LAB and it ranged from 1-12 days (in yoghurt) to 437 weeks (fermented milk with $S$. thermophilus) (Schaack and Marth, 1988). The survival of $L$. monocytogenes in yoghurt, during storage at $4^{\circ} \mathrm{C}$, was influenced by $\mathrm{pH}$ value and dry matter of the yoghurt, and content of fat had no significant effect. 
Namely, all tested strains of L.monocytogenes (3) survived longer in skimmed milk with high content of dry matter and high $\mathrm{pH}$ value compared to full fat milk with lower content of dry matter (Griffit and Deibel, 1990).

L.monocytogenes was also isolated in ice cream and frozen food, which represents another proof that this microorganism can survive freezing temperatures (Cordano and Rocourt, 2001). According to literature data, the frequency of incidence of L.monocytogenes in ice-cream ranges from 2,8-3,5\%. However, according to some researches, it is even higher. In Addis Ababa, in ice-cream samples collected from September 2003 to April 2004, L. monocytogenes was isolated in $19,6 \%$ of cases. Increased contamination of ice-cream by this bacterium is explained by very suitable environment for its growth, considering the $\mathrm{pH}$ value, water activity, availability of nutrients and storage temperature (Molla et al., 2004).

\section{Hygiene measures}

In order to prevent the contamination of milk and dairy products with L.monocytogenes it is necessary to focus and direct the attention on hygiene in dairy plant production facilities. Sanitation measures (washing with detergents and disinfection of clean surfaces) must be carried out properly. Each dairy plant must have the plan of frequency of sanitation which includes precise schedule of washing and disinfection of equipment, floors, draining pipes, walls, cold stores, etc. Very important is selection of adequate washing preparations and disinfectants, keeping in mind that disinfectants have to be changed occasionally, because it is proven that over time L.monocytogenes acquires resistance to certain preparations.

According to Food Safety Authority of Ireland (2005) chemical preparations which are considered to be most efficient against L. monocytogenes in the process of sanitation of equipment are iodoform, quarter ammonium compounds, peracetic and peroctanoic acids and solutions on the basis of chlorine dioxide.

Preparations based on idoform are recommended for use in dairy industry because their residues don't inactivate the starter cultures. Recommended concentration of $200 \mathrm{ppm}$, acting for period of 10-20 minutes, is efficient against L.monocytogenes on equipment and other surfaces. Their efficiency is reduced at temperatures $<4^{0} \mathrm{C}$ and they are unstable at high temperatures.

Quartery ammonium compounds are not recommended for direct use on surfaces which are in contact with food, because even the smallest residues of these compounds inactivate the starter cultures, but they are very efficient for washing of floors, drains, walls and cold stores.

Peracetic and peroctanoic acids have proven as very efficient means against L.monocytogenes and formed biofilms and can be used without any limitations and restrictions (equipment, floors, walls, etc.).

Solutions on the basis of chlorine dioxide are efficient in disinfection of surfaces that do not corrode. 
Steam can be used as alternative for chemical disinfection. Use of steam should be limited to equipment that is difficult for washing and cleaning, and closed systems due to forming of aerosol and condensation on equipment.

Warm water $\left(>82^{\circ} \mathrm{C}\right)$ can be used in combination with disinfectant, if producer allows preparation in warm water, and in this way the efficiency of the disinfectant is increased. When chemical disinfectants are used, the water hardness must be taken into consideration and concentrations determined by the producer must be respected. Combinations of detergents and disinfectants are not recommended because disinfectants require precise time/duration of contact with the equipment or surface in order to be efficient. In the process of sanitation it is much better to use detergents and disinfectants separately.

Floors and sewers and drains should not be washed with high pressure water, as this can lead to forming of contaminated aerosols in the production facility which can easily lead to contamination of products.

Accessories/utensils used for washing, after use, must be washed and disinfected using quartery ammonium compounds (600-1000 ppm). Also, as much as possible, the equipment, floors, accessories/utensils and all other work surfaces need to be kept dry.

It is very important that trained staff monitors the process of sanitation in dairy plant in order to ensure proper sanitation process. By introduction of HACCP (Hazard Analysis and Critical Control Points), as a new way of control in the process of production and processing the risk of contamination of products with these pathogen micro organisms is reduced. Producers identify critical points, and it is very important to determine the frequency of sampling of products and equipment used in production and processing, for testing on presence of L.monocytogenes. In this way the risk of contaminated milk and dairy products reaching the consumers is reduced.

\section{Conclusion}

Outbreaks of listeriosis in some countries, caused by consumption of milk and dairy products contaminated with Listeria monocytogenes, indicates the risk and danger to consumer health should such products be placed on the market. This emphasizes the significance and need for permanent control, and timely detection of potential sources of contamination.

L.monocytogenes is isolated mainly in raw and pasteurized milk, ice-cream, butter and other dairy products, and most commonly in fresh cheeses. Despite intensified efforts to improve the hygiene conditions in the production process, it is difficult to completely eliminate L.monocytogenes from all products, which is stated in studies by numerous authors. Conditions present in dairy plants (moisture, organic residues, temperature, etc.) are extremely favourable for development and growth of L.monocytogenes, which forms a biofilm on all surfaces (equipment, floors, walls, etc.) that is very difficult to remove and eliminate. In order to prevent 
the contamination of product with this bacterium, proper hygiene is of great importance, consistent compliance with determined sanitation plan with strict control of the whole process by trained staff.

Protection against the contamination of milk and dairy products with L.monocytogenes in the production process must be focused on control in all production stages, starting from the primary production of milk on the farm, in dairy plant, during storage and distribution.

\title{
Acknowledgment
}

The research is financed by the Ministry of Education and Science, Republic of Serbia, Project TR 31095.

\section{Listeria monocytogenes u mleku i mlečnim proizvodima}

\author{
A. Kasalica, V. Vuković, A. Vranješ, N. Memiši
}

\section{Rezime}

Listeria monocytogenes je široko rasprostranjena u prirodi. Izazivač je listerioze, ozbiljne infektivne bolesti, koja se javlja kao posledica konzumiranja hrane kontaminirane ovom patogenom bakterijom. Učestalost javljana listerioze je mala (1\%), ali sa visokom stopom smrtnosti ( $30 \%)$. U pojedinim zemljama (SAD i Švajcarska) velike epidemije listerioze bile su povezane sa konzumiranjem svežih sireva i mleka.

Ispitivanja u Evropi, na prisustvo L.monocytogenes u sirovom mleku pokazala su da 2,5-6\% uzoraka može biti kontaminirano sa L.monocytogenes. U procesu proizvodnje mleka i mlečnih proizvoda. najčešće se javlja kao posledica postpasterizacione kontaminacije.

L.monocytogenes ima sposobnost da se razmnožava na niskim temperaturama $\left(4^{0} \mathrm{C}\right)$ i da preživljava na temperaturama zamrzavanja, te kao takva predstavlja opasnost po zdravlje potrošača ako se nađe u mleku, siru, sladoledu i drugim mlečnim proizvodima. Da ne bi došlo do kontaminacije proizvoda sa ovom bakterijom proizvožači moraju da deluju preventivno, pri čemu treba posvetiti posbnu pažnju na kritične tačke u procesu proizvodnje i na pravilnu sanitaciju.

$\mathrm{U}$ radu su prikazane opšte karakteristike L.monocytogenes, otpornost prema spoljašnjoj sredini, neke epidemije listerioze, njeno prisustvo u mleku i mlečnim proizvodima i važnije higijenske mere. 


\section{References}

BECKERS J.H., SOENTORO S.S.P., DELGOU-van ASCH M.H.E. (1987): The occurrence of Listeria monocytogenes in soft cheeses and milk and its resistances to heat. Int. J. Food Microbiol., 4, 6, 249-256.

BERGEY'S MANUAL OF DETERMINATION BACTERIOLOGY 9th EDITION (1994): Edited by John G. Holt, Williams \& Wilkins, Baltimore.

BILLE J. (1990): Epidemiology of human listeriosis in Europe, with special reference to Swiss outbreak. In: A. J. Miller, J. L. Smith, and G. A. Somkuti, Foodborne listeriosis. Society for Industrial Microbiology. Elsevier Science Publishing, Inc., New York.

BILLE J., BLANC D.S, SCHMID S., BOUBACER K., BAUMGARTNER H.H.,TRITTEN L.M., LIENHARD R, BERNER D., ANDERAU R., TREBOUX M., DUCOMMUN M.J., MALINVERNI R., GENNE D., ERARD Ph, WAESPI U. (2006): Outbreak of human listeriosis associated with tomme cheese in northwest Switzerland. Eurosurveillance, 11, 6, 91-93.

BOTTARELLI A.,BONARDI S.,BENTHLEY S. (1999): Presence of Listeria spp. in short-ripened cheeses.Università degli Studi di ParmaAnnali della Facoltà di Medicina Veterinaria, Vol. XIX

BOUGLE D.L., STAHL V. (1994): Survival of Listeria monocytogenes after irradiation treatment of camembert. L.Food Protect., 57, 9, 811-813.

CONNER D.E., BRACKETT E.R., BEUCHAT R.L. (1986): Effect of temperature, sodium chloride, and $\mathrm{pH}$ on growth of Listeria monocytogenes in cabbage juice. Appl. Environ. Microbiol., 52, 59-63.

CONLY M.J., JOHNSTON M.D. (2008): Listeria: A persisteent food-borne pathogen. Can. J. Infect. Dis. Med. Microbiol., 19, 327-328

CORDANO A.M., ROCOURT J. (2001): Occurrence of Listeria monocytogenes in food in Chile. Int J Food Microbiol.,70,175-178.

DALTON C.B. AUSTIN C.C., SOBEL J. (1997): An outbreak of gastroenteritis and fever due to Listeria monocytogenes in milk. N. Engl. Med., 336, 100-105.

DONNELY C.W. (2004): Growth and survival of microbial pathogens in cheese. In: Fox, P.F., McSweeney, P.L., Cogan, T.M. and Guinee, T.P. (Eds.), Cheese: Chemistry, Physics and Microbiology, Volume 1, General Aspects (3rd Ed.), Elsevier Academic Press, 541-559.

EIFERT J.D., SANGLAY G.C. (2002): Chemistry of chlorine sanitisers in food processing. Dairy Food Environ. Sanitation, 22, 534-538.

EL-GAZZAR F.E , BOHNER H.F., MARTH E.H. (1992). Antagonism between Listeria monocytogenes and lactoccoci during fermentation of products from ultrfiltered skim milk. J, Dairy Sci., 75, 1, 43-50.

FARBER J.M., PETERKIN P.I. (1991): Listeria monocytogenes, a food-borne pathogen. Microbiol. Rev., 55, 476-511. 
FENLON D.R. (1986): Rapid quantitative assessment of the distribution of Listeria in silage implicated in a suspected outbreak of listeriosis in calves. Vet Rec., 118, 240-242.

FLEMING D.W., COCHI S.L., McDONALD K., BRONDUM J., HAYES P.S., PLIKAYTIS B.D., HOLMES M.B., AUDURIER A., BROOME C .V., REINGOLD A.L. (1985): Pasteurized milk as a vehicle of infection in an outbreak of listeriosis. N. Eng. J. Med., 312, $404-407$.

FOOD SAFETY AUTHORITY OF IRELAND (2005): The Control and Management of Listeria monocytogenes Contamination of Food.

GREENWOOD H.M., ROBERTS D., BURDEN P. (1991): The occurrence of Listeria species in milk and dairy products: a national survey in England and Wales. Int. J. Food Microbiol., 12, 2, 197-206.

GRIFFITH M., DEIBEL K.E. (1990): Survival of Listeria monocytoenes in yogurt with varyng levels of fat and solids. J. Food Safety, 10, 3, 219-230.

HAEKKINEN L., LINDJAAERV R., AUSLEETE J. (2001): Isolation of Listeria monocytogenes from raw milk. Veter. Med., 116-119.

HARRIS J.L.,DAESCHEL A.M., STILES E.M., KLAENHAMMER R.T. (1989): Antimicrobia activity of lactis acid bacteria against Listeria monocytogenes. J. Food Protect., 52, 6, 384-387.

JACQUETA Ch., ROCOURTB J., REYNAUDA A. (1993): Study of Listeria monocytogenes contamination in a dairy plant and characterization of strains isolated. Int.J. Food Microbiol., 20, 13-22.

JAY M.J., LESSNER J.M., GOLDEN A.D. (2005): Modern Food Microbiology. Seventh edition.Food Science Text Series. Springer Science + Business Media, Inc.,USA.

JAYAMANNE S.V., SAMARAJEEWA U. (2010): Evaluation of the resistance of pathogenic Listeria monocytogenes in milk and milk products in Sri Lanka. Tropical Agricult. Res. \& Extension, 13, 3,73-80.

KARAKOLEV R. (2009): Incidence of Listeria monocytogenes in beef, pork, rawdried and raw-smoked sausages in Bulgaria. Food Control., 20, 10, 953-955.

KASALICA A. (1992): Antimikrobna aktivnost združenih kompatibilnih sojeva Lactobacillus delbrueckii subsp. bulgaricus i Streptococcus salivarius subsp. thermophilus. Doktorska disertacija. Poljoprivredni fakultet, Novi Sad. UDK 637.075

KASALICA A., OTENHAJMER I. (1995a): Psychrotrophic bacteria of milk collected in a dariy farm cooling basin. Acta Veter., 45, 2-3, 137-142.

KASALICA A., OTENHAJMER I. (1995b): Types of psychrotrophic bacteria of row milk coolected in a dairy farm cooling basin. Acta Veter., 45, 5-6, 311-316.

KASALICA A., OTENHAJMER I. (1995c): Psihrotrofni mikroorganizmi u sirovom mleku. II jugoslovenski simpozijum prehranbenih tehnologa. Poljoprivredni fakultet, Zemun. Zbornik, 127. 
KASALICA A., OTENHAJMER I. (1996): Psihrotrofni mikroorganizmi u mleku. V Međunarodni Simpozijum "Savremeni trenodvi u preoizvodnji mleka", Kopaonik. Zbornik (Monografija), 46-50.

KASALICA A. (1997): Changes of antimicrobial activity in yoghurt during storage.Acta Aliment., 26 1, 1-8.

KASALICA A. (2000): Yersinia enterocolitica u mleku. J. Sci. Agric.Researc,b 61, 211, 1-2, 183-194.

KASALICA A., OLJAČIĆ E. (2007): Prisustvo Listeria monocytoenes u mleku i mlečnim proizvodima. Savetovanje. »Detekcija Listeia monocytogenes u mleku i mlečnim proizvodima«. JPS Zavod za mlekarstvo, N.Beograd. (CD prezentacija) KASALICA A., POPOVIĆ-VRANJEŠ A.: Prisustvo Listeria monocytoenes u zbirnome mleku sa farme i kod individualnih proizvođača (ne objavljena istraživanja).

KOVINČIĆ I.,VUJIČIĆ F.I., ŠVABIĆ-VLAHOVIĆ M. VULIĆ M., GAGIĆ M. WESLEY V.I. (1991): Survival of Listeria monocytoenes during the manufacture and ripening of trappist cheese. J.Food Protect., 54, 6, 418-420.

KOZAK J.,BALMER T., BYRNE R.,FISHER K. (1996): References and further reading may be availablefor this article. to view references and further reading you must purchase this article. Food Control, 7,215-221.

LINNAN M. J., MASCOLA L., LOU X.D., GOULET V., MAY S., SALMINEN C., HLIRD D.W., YONEKURA M.L., HAYES P., WEAWER R., AUDURIER A., PLIKAYTIS B.D.,FANNIN S.L., KLEKS.A., BROOME C.V. (1988): Epidemic listeriosis associated with Mexican-style cheese. N. Engl. J. Med., 319, 823 - 828.

LONCAREVIC S., DANIELSSON-THAM M.L., THAM W. (1995): Occurrence of Listeria monocytogenes in soft and semi-soft cheeses in retail outlets in Sweden. Int J Food Microbiol.,26, 245-250.

LYYTIKSINEN O., AUTIO T., MAIJALA R., RUUTU P., HONKANENBUZALSKI T., MIETTINEN M., HATAKKAKA M., MIKKOLA J., ANTTILA V.J., JOHANSSON T., RANTALA L., AALTO T., KORKEALA H., SIITONEN A. ( 2000): An outbreak of Listeria monocytogenes serotype 3a infections from butter in Finland. J. Inf. Dis., 181,1838-1841.

MAČVANIN M. (2004): Listerioza fatalna infektivna bolest sa »bezazlenim« simptomima. Sci Tech, 004, 54-56.

MAIJALA R., LYYTIKAINEN O., JOHANSSON T., AUTIO T., AALTO T.,HAAVISTO L., HONKANEN-BUZALSKI T. (2001): Exposure of Listeria monocytogenes with-in an epidemic caused by butter in Finland. Int. J. Food Microbiol., 70, 97-109.

MAHMOODI M.M. (2010): Occurrence of Listeria monocytogenes in raw milk and dairy products in noorabad, Iran. J. Animal Veter. Advan., 9, 16-19.

MARRIOT N.G., GRAVANI R.B. (2006): Principles of Food Sanitation, Springer, USA.

MARTH E.H. (1988): Survival Listeria monocytogenes in refrigerated cultured mliks and yoghurt. J. Food Protect., 51, 11, 848-852. 
McLAUCHLIN J., GREENWOOD H.M., PINI N.P. (1990): The occurrence of Listeria monocytogenes in cheese from a manufacturer associated with a case of listeriosis. Inter. J. Food Microbiol., 10, 6, 255-262.

McLAUCHLIN J., MITCHELL T.R., SMERDON J.W. (2004): Listeria monocytogenes and listeriosis:a review of hazard characterisation for use in microbiologyical risk assessment of foods. Int. J. Food Micribiol., 92, 1, 15-33.

MELANIE R., SIEGFRIED S. (2001): High incidence of Listeria monocytogenes in European red smear cheese. Int. J. Food Microbiol., 63, 1-2, 91-98.

MOLLA B., YILJMA R., ALEMAYEHU D. (2004): Listeria monocytogenes and other Listeria species in retail meat and milk products in Addis Ababa, Ethiopia. Ethiop. J. Health Dev., 18, 3, 208-212.

MUGAMPOZA D., MUYANJA C.M.B.K., OGWOK P.,SERUNJOGI M.L., NASINYAMA G.W. (2011): Occurrence of Listeria monocytogenes in bulked raw milk and traditionally fermented dairy products in Uganda. African J. Food, Agricul., Nutrit., Develop., 11, 2, 4610-4622 .

OOI S.T., LORBER B. (2005): Gastroenteritis due to Listeria monocytogenes. Clin. Infect. Dis., 40, 1327-1332.

PAN Y., BREIDT J.F., KATHARIOU S. (2006): Resistance of Listeria monocytogenes biofilms to sanitizing agents in a simulated food processing enviroument. Appl. Environ. Microbiol., 72, 7711-7717.

PAPAGEORGIOU D.K, BORI M., MATIS A. (1997): Survival of Listeria monocytogenes in frozen ewe's milk and feta cheese curd. J. Food Prot., 60, 9, 1041-1045.

PEARSON J.L., MARTH H.E. (1990): Listeria monocytogenes- Threat to a safe food sumpply: A review 1. J Dairy Sci., 73, 4, 912-928.

PINI N.P., GILBERT J.R. (1988): The occurrence in U.K. of Listeria spp in raw chckens and soft cheeses. Int. J. Food Microbiol., 6, 6, 317-326.

RUDOLF M., SCHERER S. (2001): High incidence of Listeria monocytoenes in European red smear cheese. Int. J. Food Microbiol., 63, 11, 91-98.

SALAMINA G. (1996): A foodborne gastroenteritis involving Listeria monocytogenes. Epidemiol. Infec., 117, 429-436.

SCHAACK M.M., MARTH E.H. (1988): Survival of Listeria monocytoenes in refrigerated cultured milks an jogurt. J. Food Protect., 51, 11, 848-852.

SEELIGER H.P.R., JONES D. (1984): Genus Listeria. In: SNEATH P.H.A., MAIER N.S., SHARPE M.E., HOLT J.G. (eds.), Bergey's manual of systematic bacteriology. Baltimore, U.S.A.: Williams and Wilkins.

SHELEF L.A. (1989): Listeriosis and transmission by food. Proces Food Nutri. Sci., 13, 363-382.

SCHAFER M., MURPHY M., BOYLE L. (2000): Controlling Listeria in your facility. Meat Processing News, Dept. Animal Science and Industry, Kansas State University, United States, Summer/Fall Issues.

SLUŽBENI GLASNIK RS, 72/2010: "Pravilnikom o opštim i posebnim uslovima higijene hrane u bilo kojoj fazi proizvodnje, prerade i prometa" 
TASCI F., TURUTOGLU H., OGUTCU H. (2010): Investigation of Listeria species in milk and silage produced in Burdur province. Kafkas Univ. Vet. Fak. Derg., 16, Suppl-A, 93-97.

THEODORIDIS A.K., PAPAGEORGIOU D.K., ABRAHIM A. KARAIOANNOGOU P.G. (2006): Fate of Listeria monocytogenes during the manufacture and storage of Chevre Metsovo and Pichtogalo Chanion cheeses (Greece). Italian J. Food Sci., 18, 1, 51-61.

TODAR K. (2009): "Listeria monocytogenes". Todar's Online Textbook of Bacteriology. $\mathrm{n}$ page, htt:// textbookof bacteriology.net/Listeria.html

TODDA D.C.E., NOTERMANSB S. (2010): Surveillance of listeriosis and its causative pathogen, Listeria monocytogenes. Food Control, 22, 9, 1484-1490.

TOMPKIN R.B., SCOTT V.N., BERNARD D.T., SVEUM W.H., SULLIVAN GOMBAS K. (1999): Guidelines to prevent post-processing contamination from Listeria monocytogenes. Dairy Food Environ Sanitation, 19, 551-562.

USDA (1999): United States Deparment of Agriculture 1999 Consumer Information from USDA, Food Safety Education Office, Food Safety and inspection service, USDA, Washington D.C 20250-3700, USA.

VAZQUEZ-BOLAND J.A., KUHN M. BERCHE P. (2001): Listeria pathogenesis and molecular virulence determinants. Clin. Microbiol. Rev., 14, 584-640.

VILAR M.J., YUS E., SANJUAN M.L., DIEGUEZ J.L., RODRIGUEZ-OTERO F.J. (2007): Prevalence of and risk factors for Listeria species on dairy farms. J Dairy Sci, 90, 5083-5088.

VITAS I.A., AGUADO V., GARCIA-JALON I. (2004): Occurrence of Listeria monocytoenes in fresh and processed food in Navarra (Spain). Int. J. Food Microbiol., 90, 2, 349-356.

WAAK E., THAM W., DANIELSSON-TAM M.L (2002): Prevalence and fingerprinting of Listeria monocytogenes strains isolated from raw whole milk in farm bulk tanks and in dairy ptant receiving tanks. Appl. Environ. Microbiol., 68, 7, 3366-3370.

WILKINS P.O., BOURGEOIS R., MURRAY E.G.R. (1972): Psychrotrophic properties of Listeria monocytogenes. Can. J. Microbiol., 18, 543-551.

ZUNIGA-ESTRADA A., LOPEZ-MERINO A., de la GARZA L.M. (1995): Survivalof Listeria monocytogenes in milk fermented with a starter culture for making yogurt. Rev. Latinoam. Microbiol., 37, 3, 257-265. 